\title{
The Landscape of Envisioning and Speculative Design Methods for Sustainable Mobility Futures
}

\author{
Helena Sustar ${ }^{1, *}$, Miloš N. Mladenović $^{2}\left(\mathbb{D}\right.$ and Moshe Givoni ${ }^{3}$ \\ 1 Learning Services, Aalto Open University; Espoo, FI-00076 AALTO, Finland \\ 2 Department of Built Environment, Aalto University; Espoo, FI-00076 AALTO, Finland; \\ milos.mladenovic@aalto.fi \\ 3 Department of Geography and the Human Environment: Tel Aviv University, Tel Aviv 6997801, Israel; \\ givonim@tauex.tau.ac.il \\ * Correspondence: helena.sustar@aalto.fi; Tel.: +358-40-321-9880
}

Received: 13 January 2020; Accepted: 18 March 2020; Published: 20 March 2020

\begin{abstract}
Urban mobility is facing an increased long-term uncertainty and complexity generated by accelerated technological development. These challenges require radical advancement in planning processes and methods, which could enable breaking out of path dependencies and unlocking alternative, sustainable futures. In order to provide a landscape overview of foresight-focused methods used in the domain of urban mobility, we conduct a systematic literature review. An analytical framework for review is based on planning knowledge taxonomy, including dialectic between knowing how/what and knowing to what end and doing. Such framework formulation is aiming to assess methodological capacity for widening system boundary and holism (object-focus) as well as integration and imagination (process-focus). Results show that the overall trend of methodological development is emphasizing development in object or process-focus domain, but rarely both. In addition to this assessment, we conclude that methodological development should further reflect the moral and democratic dimension concerning public deliberation. Such development should aim to create spaces for shared discussion, reflection, and formation of alternative futures, while allowing spaces for agonistic contestation and conflicting opinions through radical, experimental, and experiential approaches.
\end{abstract}

Keywords: mobility futures; mobilities; urban planning; imagination; future studies; scenarios; speculative design; utopia

\section{Introduction}

The high urgency of sustainability and related urban and transport planning actions need to be contrasted with the fact that human mobility is a domain with increasingly higher uncertainty and complexity [1-3]. In particular, rapid development of urban mobility technologies is an important source of such uncertainty [4-6]. These technological opportunities challenge the expanding decision-making domain including mobility cultures, practices, and meanings besides digital or physical infrastructures $[7,8]$. In addition to increasing complexity of planning contexts, there is additional process uncertainty from the planning activities themselves [9]. Such level of contextual uncertainty and complexity relates to a wider range of unanticipated consequences and the need for developing new steering mechanisms [10-12], while highlighting the irreducible question of distributive justice $[13,14]$.

It is widely recognized that dominant approaches in planning mobility systems have inevitable limitations in dealing with deep uncertainty $[15,16]$. Planning in such context requires pushing the boundaries of alternative futures [9], which would be used for identifying desirable futures, 
and determining action pathways for achieving those futures. Thus, there is a need for breaking out of current path dependencies through unlocking the range of alternative futures [17]. The following Figure 1 tries to depict the need for combining understanding of past pathways [18] with the expansion of future horizons, building upon a futures cone diagram [19]. Ultimately, planning while coping with deep uncertainty would actually benefit from an opportunity to shape the future, as opposed to solely responding to predicted future [16]. Furthermore, exploration of a wider range of urban and mobility futures along with their unanticipated consequences would also require adopting more experimental ways of planning [20].

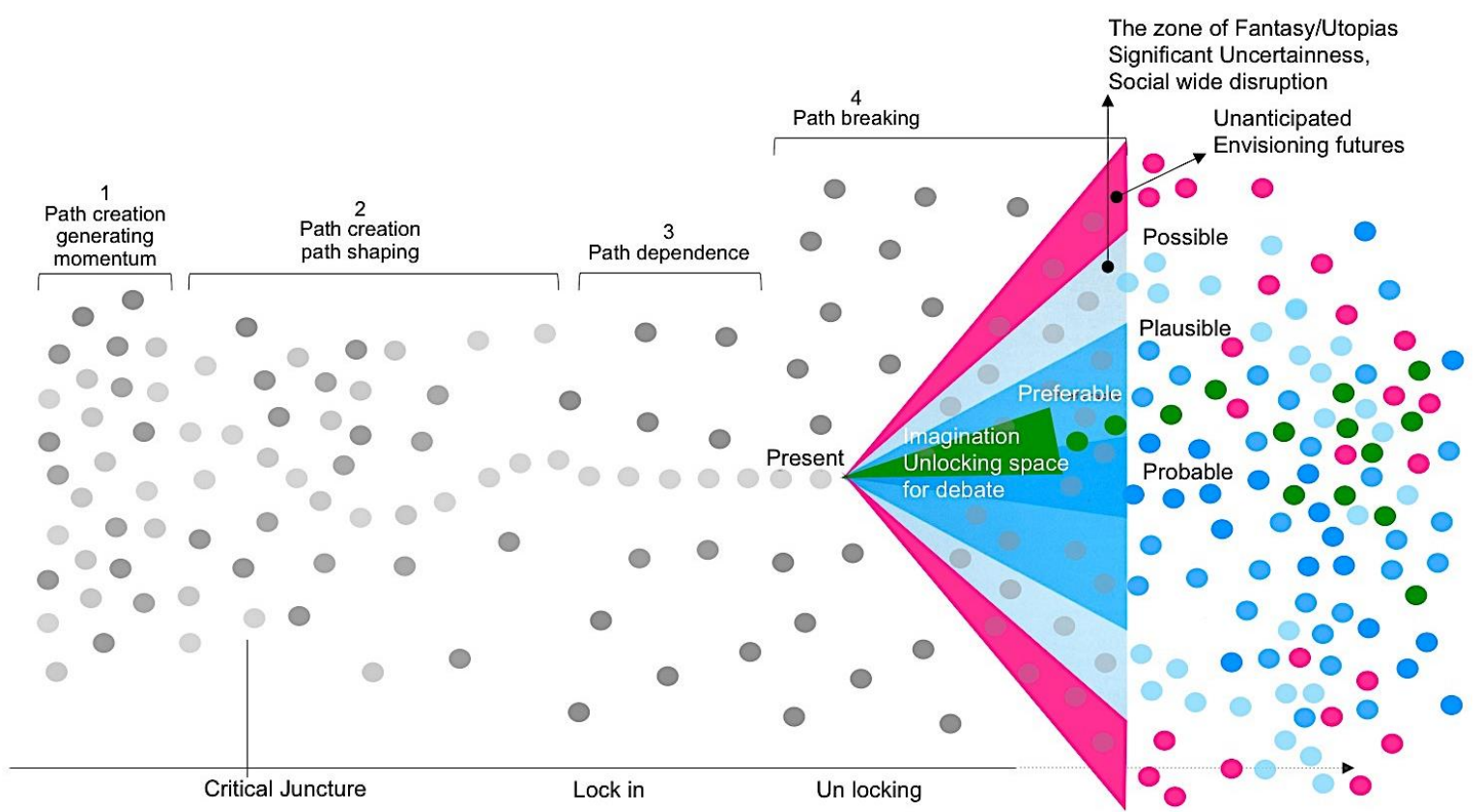

Figure 1. Unlocking pathways towards commonly desirable futures.

Following the above premises, the question arises-do we have adequate planning methods to respond to the irreducible uncertainty and complexity of mobility futures? So far, decisions about mobility futures have dominantly been based on forecasting and prediction of futures, accompanied with a range of assessment methods [21,22]. Epistemologically, forecasting of mobility relies on trend extrapolation [23], and is thus largely incapable to break out of path dependencies [24]. In particular, there is a range of reasons why forecasting as a method lacks capacity for expanding the range of alternative futures, such as simplifying human behavior, and societal or technological shifts [25-28]. Contrary to forecasting, there is a range of envisioning and speculative design methods, which have higher potential for aiding the generation of alternative futures [17,29]. In particular, there has been a range of previous reviews on the topic of envisioning [30-38]. Contrastingly, there is still a need for a systematic literature review that would focus on urban mobility and transportation as a specific field of application, while encompassing a wider set of methods. Consequently, this systematic literature review contributes to filling in this gap by providing a landscape overview of envisioning and speculation methods used in the urban mobility domain. The landscape overview is guided using the following research question-how extensively developed in terms of object and process-focus are envisioning and speculative design methods used in the domain of urban mobility, and what are general trends in their development over time? With the above aim in mind, this paper is structured as following. Section two describes methodological framework and process of the systematic literature review. Then, the following section three presents the results from the systematic literature review in more detail. The fourth section presents the discussion of results, with implications for envisioning, while the following fifth section concludes the paper. 


\section{Analytical Framework, Materials, and Methods}

\subsection{Analytical Framework Based on Planning Knowledge Taxonomy}

Developing an analytical framework for systematic review of planning methods at our disposal requires us to assume what is in fact planning as future-oriented activity. The central assumption here is that planning is a practice of knowing, i.e., knowing as something that planners do [39]. Such a premise requires understanding planning as a process of knowing and learning, where knowledge and action are interlinked, as opposed to positioning them in a linear, causal relation. Thus, knowledge is not instrumental in informing action, and practice of knowing requires us to understand multiple forms of knowing. In particular, the interrelationship between multiple forms of knowing includes at least a) knowing what (cognitive/theoretical knowledge), b) knowing how (skills/technical knowledge), c) knowing to what end (moral choices), and d) doing (action/practice). Thus, practice of knowing is a dynamic process, which exists in a particular moment and place, is both distributed and collective, as well as mediated and contested [40]. Within this context, we recognize that knowledge is embedded into our planning methods, which can contribute to more imaginative and holistic visions of futures [17,41,42]. Following the dialectic between different forms of knowing, analysis of planning methods would require identifying their capacity for supporting continuous learning of both "what" and "how". In this case, knowing "what" has an underlying emphasis on the planning objects of mobility systems, i.e., what aspects of mobility systems are being taken into consideration? In relation, knowing "how" places emphasis on planning as a process of speculative creation and learning, thus underlying its process component. The following analytical dimensions of 1) object-focus and 2) process-focus are elaborated below, defining two main axes for classification of planning methods at our disposal (Figure 2).

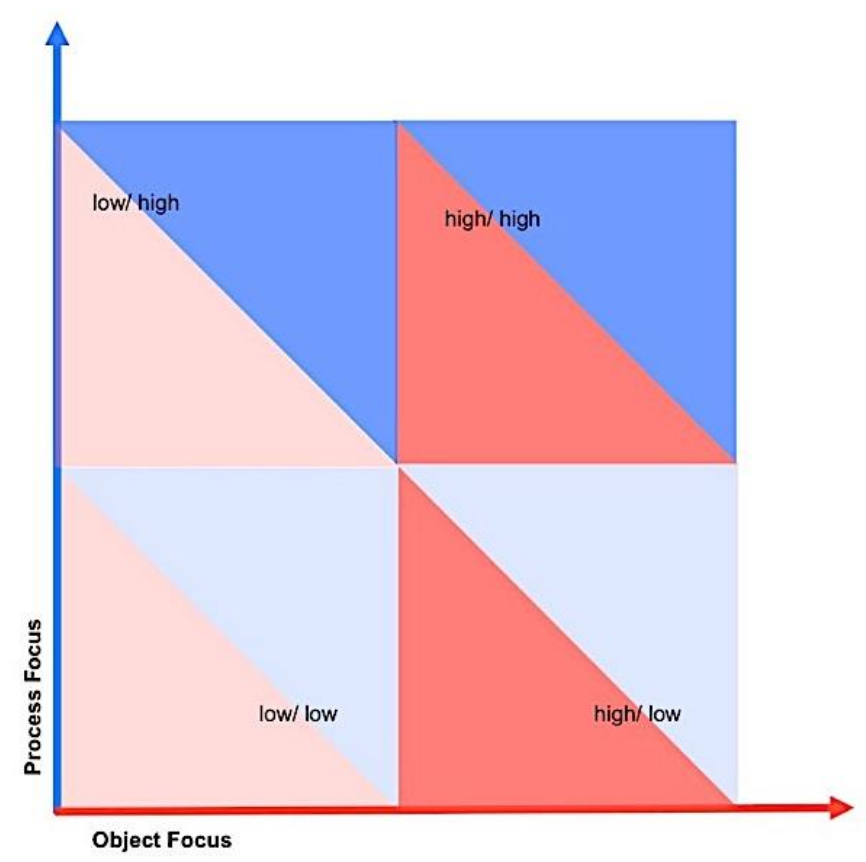

Figure 2. Framework for systematic review clustering.

\subsubsection{Object-Focus as a Synthesis Scale}

As object-focus relates to knowing what, the underlying premise is that there is a scale of what aspects of mobility systems are taken into account during envisioning and speculation [43-45]. A fully holistic standpoint would be that planning method allows focusing on interdependencies between the entire social, technological, environmental, economic, and political subsystems of mobility as a system. On the lower end of object-focus, methods would be supporting planners to explicitly focus 
on technological aspects, be it those of existing technological developments or emerging technologies, while assuming incremental or leapfrogging development. Moreover, dominantly technological focus in the planning method would also include small-scale experimentation with emerging and disruptive technologies, as well as explicit focus on multimodality mobility services. Regarding the spatial focus, the object-focus range could also vary from the neighborhood level to regional or national scale, while also having in mind a number of near-future and far-future states of the mobility system. Besides the extended consideration of spatio-temporal scales, higher development along the object-focus dimension would require that method explicitly accounts for a wider range of behavioral aspects and societal norms, as well as policy and design programs. Furthermore, positioning the method higher on the object-focus scale would also ask for methodological capacity to explicitly account for mobility practices, meanings, and cultural values, as well as a higher degree of relation to environmental components.

Process-Focus as a Synthesis Scale

As the second dimension, process-focus of the method relates to knowing how, as engaging a variety of knowledge in a creative process [46,47]. The concept of speculative imagination has an important role for defining the scale of process-focus dimension. Here, the premise is that the exercise of imagination is a mental state, different from belief that is associated to a certain probability of events possible to happen in the future [48]. Similar to belief, imagination is a representational state that has intentionality, i.e., it is about and directed at some object or state of affairs. Thus, imaginings have intentional content, but do not have to be true, as one can intentionally imagine what one could commonly assume as false. Without the constitutive connection to truth, imagination becomes a speculative, and often liberating, mental state. As essentially a constructive exercise [49] where we exercise our cognitive capacity, we can distinguish a relation between imagination and creativity. In particular, creative imagination is capacity to combine ideas in an unexpected and unconventional manner [50]. Moreover, imagination in planning has been deemed to have political, audacious, creative, and therapeutic qualities [51]. Inevitably, imagination has also been used as a concept to describe the power play in shaping different dimensions of the urban complexity, such as imaginations of spatial dynamics [52], imaginations of governance processes [53], imaginations of technologies [54], and imaginations of communities [55,56].

In particular, there are three important aspects of imaginings variation, including (a) prompts and voluntariness (i.e., process initiators and option of participation choice), (b) collaboration and form (i.e., option of collective imagination and specific rules used during imagination process), and (c) props (i.e., elements used during imagination process). Regarding the first set of aspects, process can rely solely on a limited number of experts; including selected stakeholders or non-profit sector, all the way to including general public. The usual expectation is if number and diversity of participants is expanded, that contestation of desirable futures will increase, so in this case the procedural choices is to what level can disagreement be made explicit. Related to the form aspects, procedural dimension requires consideration of both qualitative and quantitative methods, allowing comparison as well as collaborative speculation, transformation, and high level of process learning through systematic approach and communication. Finally, a range of props can relate to experimentation, design artifacts, immersion, or visualization, and storytelling that can be used in envisioning. In particular, experimentation can include further aspects of provocation and political engagement, with a higher emphasis on human experiences.

\subsection{Systematic Review Process}

Systematic review process has been following guidelines for systematic literature review in the relevant fields [57,58]. The decision was to focus on English literature, under the assumption that this is a dominant language for describing state-of-the-art planning methods worldwide. Moreover, the search was open to include journal and conference papers, as well as book chapters, scientific 
reports, and doctoral theses, with the time frame spread from 1969 until 4th of April 2018. Since journal papers from the field of design were limited, we decided to extend review also to highly renowned conferences from the field of design and human computer interaction design (e.g., Conference on Human Factors in Computing Systems). In general, the process has included four stages, namely (1) identification, (2) screening, (3) eligibility check, and (4) qualitative synthesis (Figure 3). Initial data collection started by identifying a set of references by using database search and through other sources, such as local repositories. The initial search utilized the following keywords groups: (1) Travel, transport, transportation, mobility, city; (2) imagination, visioning, utopia, creativity, alternative futures; (3) 2025, 2030, 2050; (4) low-carbon, sustainability, resilience, connectivity, smart city. We excluded words like weather, energy, pollution, food chain, airplane and rail transportation, cargo, and logistics. After this step, any duplicate references were removed. This initial phase of identification has resulted in a set of highly-cited and well-established future study methods, while also including speculative design methods. In the second, screening stage, a snowballing procedure was used to increase the pool of references [59], including both backward- and forward-snowballing [60]. In more detail, the first backward-snowballing was done by indicating the future studies methods in a publication title. Then, a forward-snowballing was applied by finding citations to a paper through the Google Scholar. In the snowballing stage, traditional future study methods were complemented with speculative design methods implemented at city planning and transportation development projects. While checking the eligibility of the increased reference set $(n=707)$, all the references were checked for eligibility, by examining a paper's title, abstract, and the text body, continuously evaluating the methods with respect to object- and process-focus. At this stage, papers that do not include significant mobility or transport component were removed, such as papers mainly focusing on land use planning. In addition, papers dominantly using forecasting approach in their methodological setup have also been excluded, and categories for clustering envisioning and speculation methods have been continuously re-examined. The included final list of references $(n=282)$ has then undergone a qualitative synthesis, using the analytical framework defined above by two reviewers, with the final assessment done by an external reviewer, not involved in the steps before. The list of journals examined in systematic review from the fields of urban and transportation planning and design is included in Appendix A.
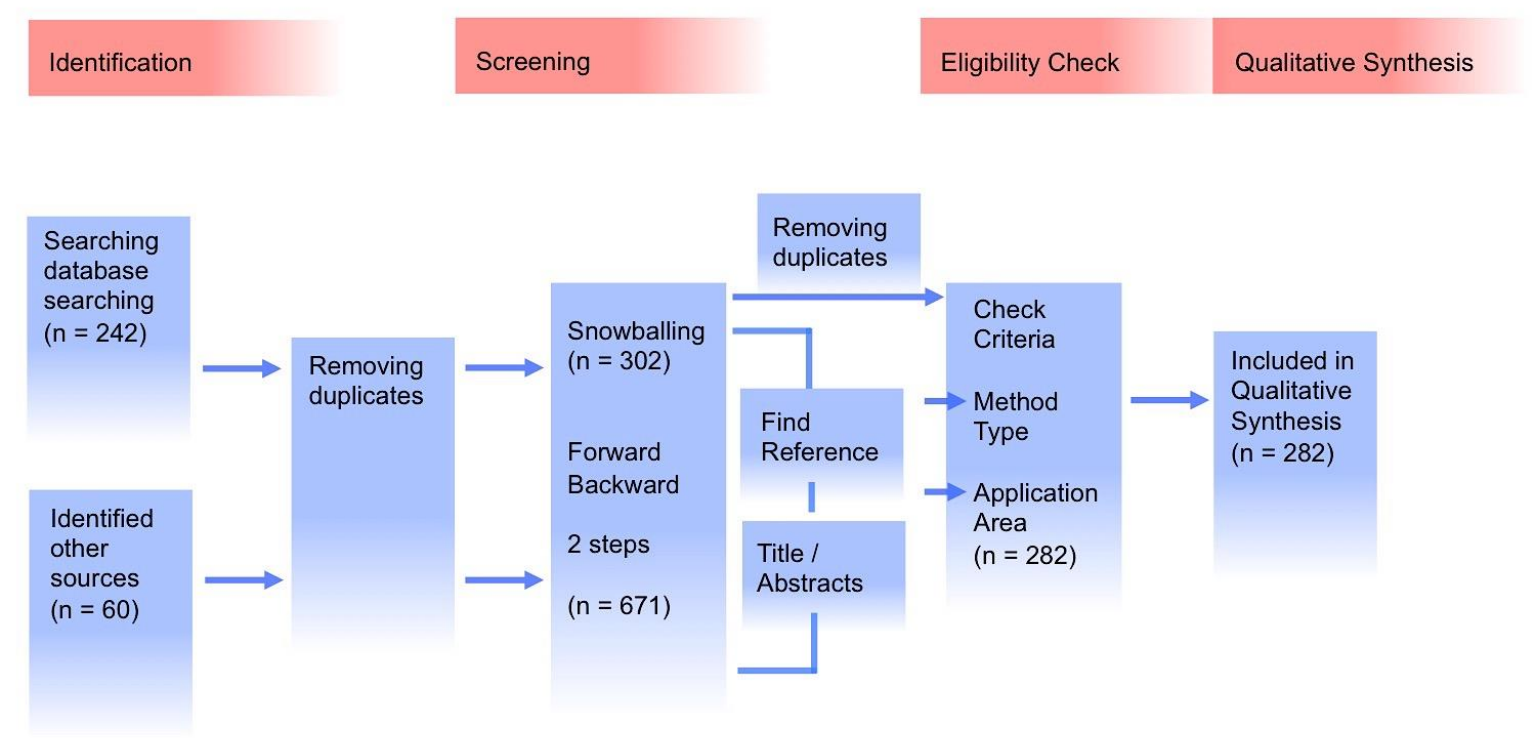

Figure 3. Review process stages and components. 


\section{Results}

\subsection{Overal Distribution of Groups and Trends}

This systematic literature review recognized a total of 282 papers, divided into five groups of unique methods. In the first group are the most numerous traditional future studies methods, with 109 papers identified. Here, we additionally distinguish individually elaborated backcasting methods, with 28 papers identified. The second is a group of methods associated with service design, such as Products-Services-Transport Systems (PSTS), which excluded technological scenarios, with 79 papers in total. The third group is focused on participatory methods with 21 papers. Then, follows the fourth group of speculative envisioning and design methods with rather higher object than process focus, including a limited number of 38 papers identified. In the last, the fifth group is the lowest number of scientific publications, with only seven publications on transportation-related utopias. Figure 4 provides an overview of method subgroups placed on the two synthesis scales. Each method is represented by a number of publications identified, and the year of the first publication identified, e.g., (number/year). From this figure, one can conclude that the most numerous methods adopted are with a low object and low process focus. The next section provides a brief description of methods, with a commentary on methods position on the landscape scale.

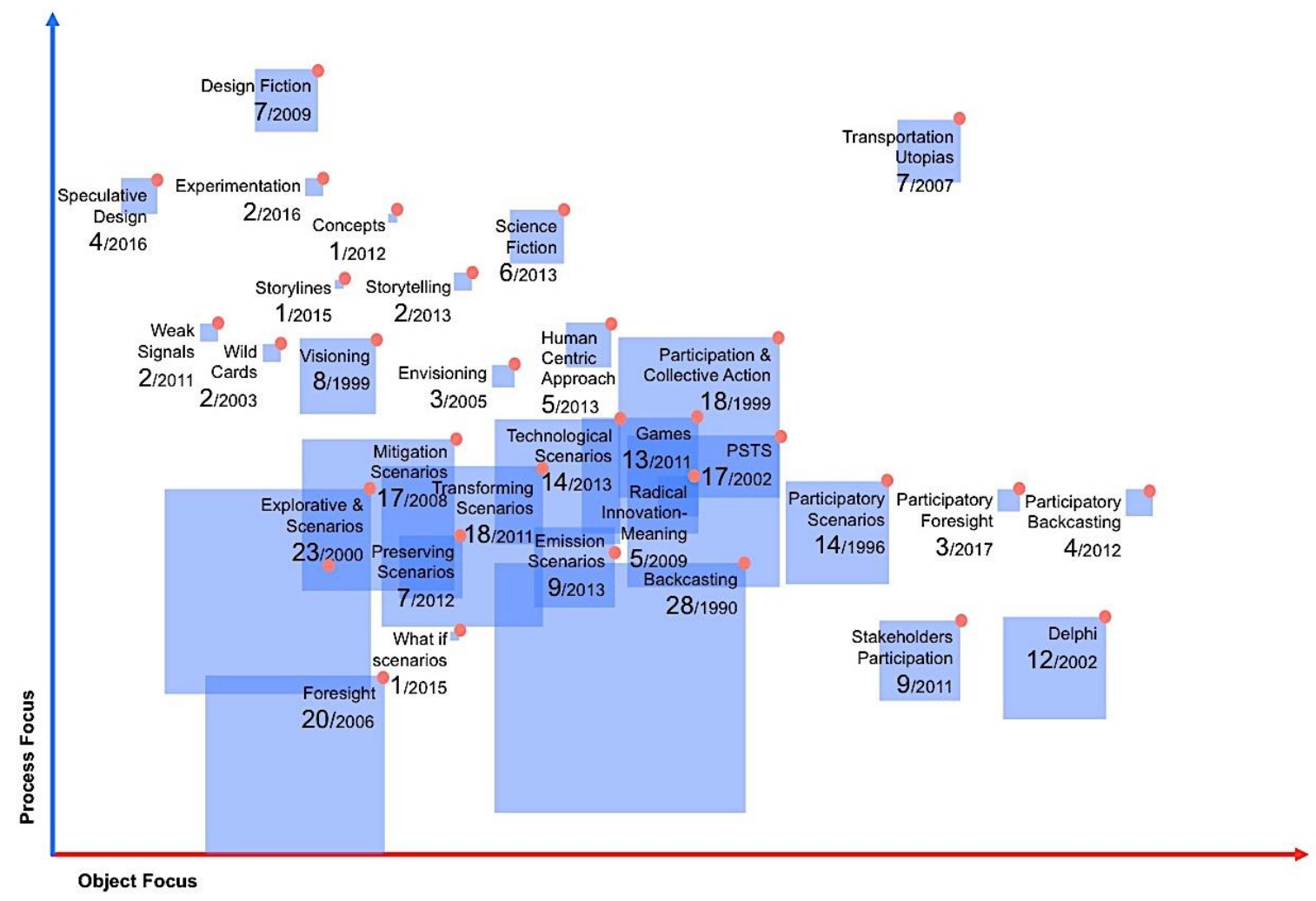

Figure 4. Landscape clustering of envisioning methods according to holism and imagination.

\subsection{Landscape Overview of Indiviual Groups of Methods and their Positioning}

The first group of methods is placed at the bottom left side of the diagram (Figure 4) because of having a low object and a low process-focus characteristic. This group includes the following methods: Foresight (20/2006), and the three different groups of scenarios: (1) Predictive scenarios (1/2015): What-if scenarios (1/2015); (2) explorative scenarios (23/2000): External scenarios (12/2000), strategic scenarios (11/2005); and (3) normative scenarios (65/2002): Preserving scenarios (7/2012), transforming (18/2011), emission scenarios (9/2013), mitigation scenarios (17/2008), and technological scenarios (14/2013). Traditional foresight methods (20/2006) are placed in the low corner of the diagram 
with the lowest object and process focus, and it is diametrically opposite to transportation utopias. Foresight methods focus mainly on identifying plausible futures. Foresight envisions future transport by adopting limited and primarily statistically significant factors of land use and travel patterns, using various software applications, such as strategic model for integrated logistic evaluations (SMILE), urban logistics models [61], and a systematic process of interconnected and iterative analysis [41,62]. Furthermore, foresight attempts to control future uncertainty and to challenge complexity with various mathematical models and socio-economic scenarios. Furthermore, because of inheriting daily routines and traditional social values, present urban problems, economic development [63], and disruptive technology-driven approaches [64], foresight methods remain limited in their future visions.

Scenarios, as the typical future studies method, generally are concerned with three questions "What will happen?, What can happen?, and How a specific point can be reached?" [65]. Scenarios envision probable, possible, and preferable futures. The first question corresponds to predictive scenarios (1/2015), which can preserve the past, and they are arduous to change the undesirable trends. In this subgroup belong 'What if scenarios' (1/2015), which are associated with unpredictable external events (e.g., floods), and decisions, such as new policies. Explorative scenarios (23/2000) respond to the second question above, which authors associate with the external (12/2000) and strategic scenarios (11/2005). Furthermore, explorative scenarios base their future predictions principally on statistically significant factors of land use and travel patterns [66-69]. They relate to the development of external factors by responding with a set of scenarios related to the long-time horizons and future developments. External scenarios progress beyond the control of relevant factors, and they are used in the strategic development, excluding policies, with the contrast to strategic scenarios, where policies are central. Strategic scenarios base their visioning on current issues, such as investing more in transit or rail transportation, and considering state rules versus local rules [70]. Combining with multi-criteria [70] and qualitative methods such as Delphi and games, or hybrids of these [71,72], explorative scenarios are opening the space for envisioning, although participation is mostly expert-based and often only in the form of surveys [73].

The next subset of methods relates to the normative scenarios (65/2002), which are divided into preserving, transforming, emissions, and mitigations scenarios. Preserving scenarios (7/2012) target aims such as, how we can meet cost-efficacy; they examine the near future energy models, short-term transportation issues, and they estimate energy consumption [74]. These methods base their predictions on past years' directions (e.g., 2010) in order to estimate futures for the target year (e.g., 2030 [73] or 2050 [75]). Furthermore, the transforming scenarios (18/2011) are developing newer paths in 25 to 50 years predictions. Transforming scenarios unlock the envisioning space by adopting backcasting, which has the starting point in the future [76-78], and by adopting participatory planning, which in [79] also include immigrants; focus groups [76], Delphi, and interviews [80,81]. Despite the expansion of imaginative space in the form of human engagement and collaboration with stakeholders, there was no experimentation, visualization, artifacts usage, or immersions identified. An exemplary exception is [82], which aimed to make regional futures more tangible and concrete by synthesizing, downscaling, and visualizing climate change scenarios.

Emission scenarios (9/2013) in this group examine greenhouse gas emissions, and envisioning towards more alternative transport systems by reducing motorized travel [83], with utilizing electric vehicles [84,85] and biofuel [86]. If emission scenarios are not focusing on policies, mitigation scenarios (17/2008) perform that. They outline a systematic and logical framework on how to develop policies to reach cleaner transportation [87]. Mitigation scenarios focus on reducing emission study policies, which are also influencing the stabilization of $\mathrm{CO} 2$ concentration. These scenarios are more proactive than other types by calling for immediate action, behavioral change, and alternative solutions [88]. For example, these scenarios aim to reduce travelling and enable more efficient and cleaner transportation in short-term visions [89]. They outline a systematic and logical framework on how to develop policies for cleaner transportation [87] and low carbon society. Furthermore, to foster change, they utilize methods like backcasting [90] and Delphi [91]. For example, [92] classifies this type of hybrid scenarios, because 
of combining qualitative and quantitative information, and responding to socio-cultural changes. Last but not least, in this group of low object and process focus methods, there are also technological scenarios. These scenarios embrace technological development of future transportation industry, such as self-driving and connected vehicles [93], and study how these technological developments affect transportation policies [94]. Furthermore, papers in this group are investigating transport planning for these emerging technologies, including travel behavior and environmental consequences [95]. Despite that, they are adopting the same principles for predicting future, as scenarios from previous groups, such us estimating passenger vehicle energy-use and assessing the future vehicle fleet electrification. These scenarios are closely connected to Products-Services-Transport Systems, which are placed closer to participatory scenarios, as they are more process-oriented than any of the methods in this group.

We placed backcasting (28/1990) on the intersection between low and high object focus methods. The reason is in its potential to predict desirable futures and be able to break with current trends by adopting utopias and participation, and in this way, explore alternative pathways and values. In 28 papers, backcasting was utilized to envision alternative transport systems, policymaking, and imagining future images, and to envision radically different future transport solutions. However, traditional backcasting is somewhat limited in being object focused with concentrating on energy or CO emission reduction [96-99], instead of moving towards low-carbon society and behavioral change by involving actors, stakeholders, and governmental institution [100].

Following is a group of methods jointly associated due to capability to affect a broader range of behavioral changes: Products-Services-Transport Systems (PSTS) (17/2002), radical innovation through the meaning (5/2009), games (13/20011), Delphi (12/2002), stakeholders participation scenarios (9/2011), human-centric approach (5/2013), and citizens' participation (18/1999). This group of methods has broad object-focus, with environmental concerns utilized through meanings, and cultural values provoking behavioral changes and transformation of current transport policies. Here, alongside [65] scenario division, we utilize [63] three generations scenarios classification. This classification comprises (1) experts' scenarios, which support exclusively expert knowledge for future forecasting; (2) hybrid scenarios, which include politicians and local government in their preparations; and (3) participatory scenarios which, with formal and intuitive methods, involve non-profit sector to enable inclusive dialogue, new forms of dialogue with people, and business within different policy levels [63].

PSTS (17/2002) are strongly interconnected with technological scenarios elaborated above, by utilizing developments in vehicle technology and smart mobility in their novel business models (e.g., Mobility as a Service). PSTS act in the present towards preferable futures by developing systems-oriented service innovations. They examine transportation systems more holistically [101]. Secondly, for their developments, they utilize radical innovation by employing meaning and games to influence individual passenger behavior change while driving, which can lead to changed vehicle ownership and sharing practices. PSTS propose new business plans for service providers and passengers. Thirdly, we identified PSTS's connection with experts' participation through Delphi and stakeholders' participation via stakeholders' participation scenarios and this way, an extension towards the human-centric approach. Recently, these methods moved from more passive participation towards citizens' participation, which was possible with the development of disruptive technologies. PSTS command a 'higher-order' learning amongst stakeholders; novel infrastructure and institutional practices; innovative vehicle design, manufacture, and end-of-life management; new forms of vehicle ownership; and novelties in producer-user interactions. PSTS are a relevant example of high object-focus methods as they acknowledge a higher impact on the environment than the traditional business decision-making. Furthermore, technological solutions that are focusing on customers' needs [102,103] enable a system of diverse shared mobility possibilities, offering alternative transitions pathways towards more sustainable systems [104]. Furthermore, papers applying radical innovation via meaning (4/2009) permit a new understanding of products through aesthetic reflection and developing innovation practices [105]. 
As an example, we identified the development of a new electric mobility solution under the constraints of sustainability-related targets [106,107].

Next, games (13/20011) use unconventional nature of problem-solving and decision-making focus on an individual's behavior thought motivation. Small-scale studies that employ games, empower an understanding of complex social-technological systems performances, managing personal mobility, and individual behavior change in the automotive domain. Due to their capability for stirring sustainable motivation and strong commitment $[108,109]$, games also promote sustainable urban mobility [110,111]. Moreover, Delphi $(11 / 2002)$ is used as a constructor of future experts' scenarios, basing its predictions on differences and similarities in experts' knowledge collected via surveys [112-116]. Some cases engage stakeholders in predicting the future $[112,114,117]$. On the one hand, Delphi, similarly as scenarios, is set into everyday routines and undertakes issues related to the local government, policy, market [112], and customer preferences [117]. Furthermore, Delphi sets its actions in the long-distance futures of the year (e.g., 2050 [118]) and endeavors the most probable [117,119] desirable [117], and preferable futures [120]. Despite some limitations, [113] claim that Delphi creates futures, rather than predict them; therefore, this is the valuable method when dealing with intense and uncertain changes over an extended period.

The next method in this group is stakeholders' participation scenarios (9/2011), which combine traditional approaches, such us focus groups and scenario planning methodology. It is characteristic for this method that it is opening and provoking up-to-date discourses, and consequently enabling a plurality of different possible futures. [121] states that the stakeholders, researchers, and decision-makers, industry, policymaking, and social science actors' engagement in scenarios can increase communication between them. However, some researchers note that users have limited knowledge on predicting the consequences of their and governmental actions' in plausible future developments [122,123]. In contrast, in the human-centric approach (5/2013), the passenger is at the center of future solutions [124]. The user is engaged in the participatory and co-design processes through transport diaries, future fictions, and exploratory design workshop acknowledging individuals' needs, experiences, human senses, desires, and values, which are established as apriority for transport services. Hereabouts, passengers' requirements, desires, and values are employed to improve the functionalities of existing transport services [124]. For instance, [125] users participatory and co-design methods, such us transport diary, were adopted to record individual passenger's experiences and needs when developing a carrier bike. Furthermore, [126] utilized participatory tools, for example, future fictions and exploratory design workshop, to evaluate drivers' integration with the car, and to study human senses, such us comfort, control, sensation, and human-like auditory-verbal communication.

The last notable group of methods in this group is the citizens' collective action methods (18/1999), where institutional and governmental transport service providers act as supporters, rather than the primary providers. For example, when the local communities provide infrastructure for collaboration and consumption of shared transportation [123]. This group focuses on co-design, co-creation, co-production, and citizens' participation, expertise, and speculative inquiry, where participatory partnership spread from partnership towards delegated power. [127] paper is the first, which significantly indicates a clear emphasis on consulting the public. The next significant move towards recognizing the value of public knowledge co-creation and experiences is their connection with living labs, which enable innovation towards future sustainable growth and transformation [128]. Unfortunately, according to $[129,130]$, this field continues to be unexplored. Furthermore, disruptive technologies, such us the Internet of Things and social media, enabled people to connect with similarly minded individuals around the world, to question dissatisfying top-down models of governing, and facilitate new forms of bottom-up democracy [131]. [131] states the importance of re-democratization and citizens' engagement directing towards alternative transport policy, and re-establishing of current democratic practices in transport planning. [123] report on "planning for sharing", which provide a base for citizens to advertise and share infrastructure for collaborative consumption. [131] introduces explorations of citizens' capabilities to influence political decisions on transport investment priorities, 
specifically their opposition and mobilization of action through the spaces of connection, which allow the formation of politically new transport planning paradigms. Finally, a significant transformation is enabled with the introduction of public envisioned participation in artistic and technological experimentation, speculative design, and Do-It-Yourself (DIY) concepts [132].

Recent research builds on a diverse knowledge exchange with a participatory approach, including, for example, pluralistic backcasting [133,134], dynamic participatory process [135], and experimental design methodologies, to create images of more concrete and comprehensible futures [136]. Thus, the third group of methods, including participatory backcasting (4/2012), participatory foresight (3/2017), and participatory scenarios (14/1996), has been located on the right side of the diagram, as they are high object focused, and they are low on the process side. Participatory backcasting, participatory foresight, and participatory scenarios continue the tradition of future study methods with the rigorous implementation of normative scenarios, Delphi, backcasting, foresight, and horizon scanning techniques, but also surveys and semi-structured interviews to predict the desirable future in 30 to 40 years [137]. For example, [138] implemented normative scenario elements, which had been integrated into explorative, normative, and backcasting scenarios to achieve far-reaching greenhouse gas reduction targets in the year 2060. Furthermore, [139] states that participatory backcasting (4/2012) has to be controlled, transparent, and performed responsibly and truthfully with stakeholders. On the contrary, [140] state that participatory foresight (3/2017) is an analytical tool enabling the developing of alternative futures in science, technology, and socio-economic systems by connecting visions of different stakeholders' groups, which can contribute to different decision-making processes in various levels. [141] in the participatory scenarios (14/1996) employed a series of future visioning workshops and visualizations focused on visual techniques for designing radical future concepts and sustainable urban living. Despite researcher's non-deniable progress towards embracing alternative and fiction approaches, these participatory scenarios are yet acting and predicting for long distant futures (e.g., 2040 to 2050) $[142,143]$. Finally, [144] claim that participatory approaches utilize visionary implementations and collective visioning with participants to enable empowerment, building ownership and positive visions as an essential stimulus for change [144].

This group also includes visioning (8/1999), envisioning (3/2015), storylines (1/2015), storytelling (2/2013), wild cards (2/2003), and weak signals (2/2011). The subgroup is on the one hand associated with the traditional study methods, and on the other well-known for imaginations of communities, collaboration, and form with participation not only experts, but also stakeholders and general public. Visioning (8/1999) has higher emphasis on object-focus than the process-focus. To illustrate, in its participation activities traditional methods, like focus groups, surveys [145], and in-depth interviews [146,147], are still widespread. Recently, "community visioning" to describe pictures from the future had been utilized $[146,148]$, involving citizens to develop state transportation plan, which was before traditionally in the domain of government and transportation professionals. Other examples of such alternative visions are walking and cycling urban transport systems for the year 2030, informed by 'utopian thinking' [149] and visions for users' behavioral changes towards electric vehicles [2,150]. [151] claims that visioning exercises enable illustrating possible transition paths towards sustainability with concerns that experiences are seen solely as enthusiastic experimentation. Envisioning (3/2005) made a step further in imagining the future through the participation of people with a comprehensive set of knowledge by adopting design tools in the transformation process of producing new future visions of sustainable urban transformations to promote social dialogue and innovation [152]. Even if envisioning is associated with traditional future study methods of scenario planning and system dynamics modeling, the more recent literature [153] includes prompting of disruptive forces for enabling speculation, projection, and negotiation in the process of co-designing desirable futures. Wild cards (2/2003) and weak signals (2/2011) are other minor clusters of methods, which mission is that wild cards discontinue and agitate trends, as weak signals (e.g., mass transport attacks [154]) can influence the big picture [155]. Wild cards can have high impact, but a low possibility that they will happen, although they have to be considered to be possible [155]. Furthermore, storytelling (2/2014) utilizes a 
mixture of methods, for example, [156] applying actor-network theory and critical planning theory on one hand, and systems thinking and utopias on other, when implementing urban technologies. [150] analyses the role of frames and narratives in constructing stories of the future through two cases of electric vehicles and car clubs. Similarly, storylines (1/2015), which base on future scenarios, adopt a mixture of quantitative and qualitative methods, such us stakeholders' workshops, interviews, and participatory methods; then, prompts in the form of video scenarios [152] visual symbols and native stories to imagine future images, and to advocate drivers for change towards sustainable mobility alternatives [157].

The fourth group of methods is the typical representation of methods with a high level of process focus, imagination, and high speculation provoking 'political' debates in transportation encountering speculative design methods (4/2016), design fiction (7/2009), science fiction (6/2013), concepts (1/2012), and experimentation (2/2016). Methods in this group are in moderate numbers and are utilized in the urban transportation domain more recently. Adopting these methods, researchers are questioning current transportation and mobility paradigms in fast-developing cities focusing on citizens' welfare, well-being, sustainability, and current mobility practices. Methods search for answers through an experiential science and practice learning approach [158]. Speculative design discipline is the management of speculation informed by the use of technology, aesthetics, behavior, interaction, and function of the designed artifact $[19,159]$. Speculative design $(4 / 2016)$ describes how a combination of up-to-date extrapolations of emerging technologies and innovative practices employed in film, literature, ecology, comedy, and psychology can be used to develop and present plausible futures [159]. These medias prototype and conceptualize possible futures by creating imaginative projections of alternative futures using design images and objects [160]. For example, [161] investigate the consequences of self-driving vehicles utilizing three long-term scenarios. [141] moved away from the current trajectories of future development to develop alternative urban futures with co-creating scenarios and future visions workshops. Furthermore, experimentation (2/2016) utilizes via prompts in the form of virtual experiments, the design visioning, and the design research [153]. [153] city transformation study engaged the following voluntariness: Environmental researchers, students, and professional designers to stimulate rapid innovation, enable participatory visioning, and strong communal ownership. Differently, [151] adopted experimentation and visioning, which resulted in tangible and measurable outcomes. [151] claims that visioning exercises enable exemplifying of possible transition paths in the direction of more sustainable solutions; unfortunately, these experiences are referred only as enthusiastic experimentation.

The next method is the design fiction (7/2009), which critique preferable futures through speculative and provocative scenarios narrated with design artifacts [19]. Design fiction is an intersection of design and storytelling, and "a conflation of design, science fact, and science fiction" [162]. To speculate about the futures that are yet to come [163] and creating fictional world researcher utilizes imaginary objects [164], appropriating technology (interactive dimensions) [165], art (speculative dimensions), and science fiction (narrative dimensions) [166]. In some cases, design fiction deals with the imagination and materialization of possible futures in the form of utopias, dystopias, and experiments [163]. However, the value of design fiction is in the introduction of advanced design, anticipation, and related process to the broader community, and not only to the experts. In this way, the design projects are open for discursive fictional space, which enables exploring, sharing, imagining, and projecting participants into alternative options towards possible and preferable futures. This bottom-up approach allows perspectives different from subjective and preferred ones, which are usually advocated by top-down power [166]. Finally, the last method in this group is science fiction (SF) (6/2013), which encounters the different roles for developing future transport scenarios. According to [167], SF does not anticipate, but actively shapes technological futures through collective imagination. [168] identified the relationship between the real world of science and technology, and innovation, SF, and speculative fiction as a process, which enables transformation. [169] recognized the role of SF in creating prototypes of imaginative futures and exploring possibilities for future utopias and dystopias, as seeds of prototypical 
stories that can be planted in distant futures. [170] explored Interactive Science Fiction Prototyping as a tool for imagining, exploring, and exploiting future technologies, science, and environments in virtual worlds to look into future transport scenarios. Finally, [171] compared future studies, storyboards, and SF possibilities to challenge communication about future transport systems.

The last group of methods consists of transport utopias (7/2007) only, which are highly-object and process-focused, and completely opposite from existing trend extrapolation forecasting methods [24]. Combined with design fiction, [163] define utopia as "an ideal community or an imaginary society or place that contains highly desirable or perfect qualities". Furthermore, according to [24], utopia is a type of scenario, a static image or dynamic process, constructed in the present day of the future. It is a tool, which reflects on a current state of transportation, contrasts the current transport models, and provides longer-term visions than forecasting [24]. The opposite of a utopia is dystopia (ibid), which is nonexistent in the transport. It is set in a speculative future and can make us uncomfortable and give us a feeling of misplaced space [163]. Dystopia(s) comprehend a direct or indirect critique of current society [163]. Papers in this group propose radical utopian transport models, targeting a break from the current car dependency system [171-173]. To demonstrate, [24] proposes four possible transport utopian scenarios: Fast-high mobility, high but slow mobility, low mobility, and hybrid mobility, which are based on the current transport modes and introduce diverse mobility utopias. These models are based on fundamentally different forms of political systems, national geographical organizations, international borders, egalitarian principles of lifestyles, and radically different orders. [174] introduced 'digital panopticon' utopia, a worldwide global future forecast of transportation and mobility, with a long-lasting future envisioning. These utopian scenarios consider the entire global system, including satellite tracking, video surveillance, data mining software, biometric security, Google's vehicles, automated software systems for allocating road space and tracking individuals' carbon allowance [174]. Specific utopian scenarios outline the transformation of the person, too. These extreme future scenarios can be withdrawn if transformation moves over the tipping point of the 'digital panopticon'. Finally, the last two decades indicated the decrease of socially related utopian thinking [24]. Even more, the author states that utopian thinking is almost non-existent in transport planning, and that there is a need to investigate these forms outside of transport planning.

\section{Discussion}

The review has identified several significant trends in the overall landscape of futures methods used in mobility studies. First, recent years see a rise in the number of socio-technical factors taken into consideration in the conventional scenario methodologies [95]. Second, recent years also see a higher sensitivity towards the use of alternative and utopian methods than before [175]. However, the use of non-traditional future study methods is still on the outskirts. Overall, concerning the axes in Figure 4, there seems to be a trend of methods expanding upon object or process-focus, while there are rarely methods that account for both of these dimensions. Thus, the landscape seems to be quite crowded in the low object and process area, while still having quite significant gaps in methods with high object and process-focus. Going back to the analytical framework used for review, knowing what and knowing how should be reflected upon to the other two forms of knowing-knowing to what end and doing. The third and fourth knowledge forms of moral choices and action imply that the choice of methods needs to be reflected through the lens of social justice, and democracy concerning public deliberation required for planning activities. Consequently, the question is-does the landscape of our current methods include the capacity to create spaces for shared discussion, reflection, and formation of alternative futures [9] and unpacking the complexity of uncertainty [1-3], while also being allowing spaces for agonistic contestation and conflicting opinions through radical and experimental approaches [20]? The short answer would be-no.

Dealing with an increased uncertainty and complexity in urban and transport planning, while considering numerous sustainability issues, requires methods which embrace disruptive technologies and expand decision-making process while taking into account mobility cultures, practices, 
and meanings. One important aspect we would underline as missing is a stronger emphasis on complex entanglement between human and natural systems [176] in steering urban mobility transition. In fact, implemented methods too often talk about socio-technical systems, limiting the object-focus boundary. In addition, following the logic of PSTS, methods should also consider innovative steering mechanism in the form of mobility business models. Saying this, PSTS might not be the representative example of distributive justice, neither for service providers nor for passengers. As evident from the methodological landscape, we lack implementation of high-process and high-object focus methods, such as those combining the capacity of scenarios to systematize uncertainties and reduce decision-framing bias [64] with those with those liberating thinking aspects of speculative design [19]. Creative process-focused methods [46,47], which embrace imagination and speculation, are currently in the minority, usually covering a small geographic scale. However, with speculation, they can bring fresh and unexpected views, and enable diversion from certain probability of events, providing a unique view on mobility matters. In the future, these approaches can be extrapolated outside predominantly small-scale design domain when paired with object-focused methods used in the larger scale of the mobility domain. In particular, speculative design methods can contribute with the embracing of citizen activism and unlocking of political space, primarily through the use of design artifacts and co-design principles that can highlight the doing form of knowledge [19]. Furthermore, we have to recognize that more policy experimentation-focused approach also has challenges [151], especially since politicians do not generally want to be associated with a failed experiment. While developing more experimentation-focused approaches, we should move beyond traditional artifacts used, such as illustrations or videos. These artifacts fail to immerse the participants in the envisioned future, failing to create reflective engagement about experiences and resulting consequences. Besides, the use of personas common in design studies can potentially enrich envisioning methods [177] with a capacity for understanding distributive effects, and explicitly taking into account natural systems as a key stakeholder.

Another vital lesson from the comparative analysis is that development of envisioning methods should include stronger value focus, such as the one used in utopias, with examples of freedom or fairness [24]. The question of transparency about the values we want to protect when moving into futures space is also a question of what values we might want to speculate of leaving behind (e.g., heteronormative patriarchy, obsessive technological efficiency, and human as consumer in the market). Here, the concept of everyday, as developed in philosophical aesthetics [178] can be a useful stepping-stone for further development of envisioning approaches that can bring about better anticipation of consequences on less measurable aspects, such as meanings and values. In addition, development of future studies methods in urban mobility will have to acknowledge their essential relationship to storytelling, rhetoric, and metaphors developing deeper meanings of (un)desirable futures. Here, we can draw from well-developed future studies methods that rely on explicit account of metaphors and narratives [179-181], which can be combined with in-depth studies of narratives and imaginaries around urban mobility technologies $[182,183]$.

Indeed, the use and development of high-process and high-object focused methods will face severe challenges of transdisciplinary approaches, such as interpretative and procedural ones. Besides, such methodological development will face questions about accuracy and validity, such as those related to replication [184]. Nonetheless, further mainstreaming of future studies methods in the domain of urban mobility will have to provide a more explicit formalization of methodological components. In contrast with decision-support systems literature [185], many of the implemented methodologies lack detailed descriptions or visualizations of steps and relations between those steps, thus requiring from the reader additional interpretation in order for the methodology to be applied elsewhere. If researchers see such issues through the lens of long-term organizational learning in multi-actor and dynamic social processes of planning practice [186], they would have to start with developing empathy for the practitioners [187]. If the advanced methods are to be used in practice and for acting in the times of climate crisis, their operationalization will require in-depth understanding of complex everyday realities of those who should use these methods in practice, often facing lack of resources or time. 
Finally, an obvious next research direction in the domain of urban mobility futures methods is clustering and relational analysis using bibliometric data, aiming to establish further categorization (e.g., research location, institution, journal, etc.). Following established methodologies for such analysis [188] such a study could provide additional interpretation for associated trends in this study.

\section{Conclusions}

This systematic literature review attempts to investigate and map out the landscape of envisioning and speculative design methods used for planning of more sustainable and human-centered mobility futures. The review examines the range of envisioning future methods used in urban mobility while attempting to extend these frontiers with speculative design methods. For landscape assessment, the review utilizes planning knowledge taxonomy framework for systematic review clustering, including knowing how, knowing what, knowing to what end, and doing. Results show several trends, first in the form of rising socio-technological factors expanding the conventional scenarios. Second, there are diverse applications of experimental, speculative, and utopian methods, although still in modest numbers. The third overall conclusion indicates a lack of methods that consider the high object and process focus at the same time. Finally, identified methods, unfortunately, do not often result in a higher focus on social justice or democracy, taking into account a broader aspect of actors, including the wider public. The result is a lack of shared discussion, reflection, and alternative formation spaces that can unpack complexity and uncertainty with radical and experimental ways of doing. Therefore, in the future, methodological development requires considering qualitative and quantitative methods allowing systematic comparison, deliberative and collective imagination, speculation, transformation, as well as the high level of process learning.

This study has certain limitations, as it did not examine in detail the context of specific methods' implementation or usage. Furthermore, the study did not examine in-depth whether the method was applied individually or in a group with other methods and how this could affect the final implementation, as some of the methods were implemented in combination with other methods, which was more common for methods with a lower level of imagination. Furthermore, the planning landscape is continuously changing, and it is daily affected by emerging technologies, which in this study were not explicitly and deeply examined or classified. Here, we would like to conclude that for urban mobility planners, the future of mobility planning can be a field of uncertainty, but can also be a field of liberty and ultimately, the field of power. Nevertheless, as human beings in the age of climate crisis, we are entitled to reclaim futures as plannable space shaped through collective human action, allowing us to advocate for broader and sustainable future horizons.

Author Contributions: Conceptualization, M.N.M., H.S., and M.G.; methodology, M.N.M.; validation, M.N.M., H.S. and M.G.; formal analysis, H.S.; investigation, H.S.; resources, M.N.M. and H.S.; data curation, H.S.; writing-original draft preparation, H.S. and M.N.M.; writing—review and editing, M.N.M.; visualization, H.S.; supervision, M.N.M. and M.G.; funding acquisition, M.N.M. All authors have read and agreed to the published version of the manuscript.

Funding: This research has received partial support from the Academy of Finland, through BEMINE-project (No. 303538) and FINEST-TWINS Center of Excellence (No. 856602).

Conflicts of Interest: The authors declare no conflict of interest.

\section{Appendix A}

- $\quad$ ACM Computing Surveys

- Advances in Mechanical Engineering

- $\quad$ American Journal of Environmental Policy and Management

- $\quad$ Applied Energy

- $\quad$ Applied Mechanics and Materials

- $\quad$ Artifact: Journal of Design Practice

- Atmospheric Environment 
- Design and Culture

- Design Issues

- $\quad$ Deign Studies

- $\quad$ Ecology and Society

- Energy

- $\quad$ Energy Policy

- $\quad$ Energy Research \& Social Science

- $\quad$ Energy Strategy Reviews

- $\quad$ Environmental Science \& Technology

- Environment and Planning

- Environment and Planning B: Planning and Design

- Environmental Impact Assessment Review

- European Journal of Futures Research

- $\quad$ European Journal of Innovation and Management

- European Journal of Transport and Infrastructure Research

- Foresight

- Futures

- Global Change Biology

- $\quad$ IATSS Research

- $\quad$ IET Intelligent Transport Systems

- Innovation Organization \& Management

- Innovation: The European Journal of Social Science Research

- International Journal of Forecasting

- International Journal of Physical Distribution and Logistic Management

- International Journal of Sustainable Transport

- International Journal of Urban and Regional Research

- International Journal of Vehicle Design

- Journal of Applied Meteorology and Climatology

- Journal of Cleaner Production

- Journal of Design Research

- Journal of Future Studies

- Journal of Environmental Management

- Journal of Environmental Planning and Management

- Journal of Occupational Science

- Journal of Planning Education and Research

- Journal of Risk Research

- Journal of the American Planning Association

- Journal of Transport Geography

- Journal of Transportation and Land Use

- Journal of Urban Design

- Journal of Urban Planning and Development

- Land

- $\quad$ Landscape and Urban Planning

- $\quad$ Local Environment: The Int. Journal of Justice and Sustainability

- $\quad$ Long Range Planning

- Mobilities

- $\quad$ Nature and Culture 
- $\quad$ Planning Theory \& Practice

- $\quad$ Progress in Planning

- $\quad$ Public Administration and Development

- Public Understanding of Science

- Public Transport: Planning and Operation

- Research Evaluation

- Studia Politica Tamperensis

- Sustainability Science

- $\quad$ Technology Analysis \& Strategic Management

- Technological Forecasting and Social Change

- $\quad$ The British Journal of Sociology

- $\quad$ The Design Journal

- $\quad$ The International Journal of Justice and Sustainability

- Transportation

- Transportation Research Part A

- Transportation Research Part C

- Transportation Research Part D

- Transportation Research Procedia

- Transport Policy

- Transport Reviews

- Transportation Planning and Technology

- Transportation Research Record

- Urban Studies

- $\quad$ Urban Water Journal

- World Future Review

\section{References}

1. Hodson, M.; Geels, F.; McMeekin, A. Reconfiguring urban sustainability transitions, analysing multiplicity. Sustainability 2017, 9, 299. [CrossRef]

2. Iwaniec, D.M.; Cook, E.M.; Barbosa, O.; Grimm, N.B. The framing of urban sustainability transformations. Sustainability 2019, 11, 573. [CrossRef]

3. Zinkernagel, R.; Evans, J.; Neij, L. Applying the SDGs to cities: Business as usual or a new dawn? Sustainability 2018, 10, 3201. [CrossRef]

4. Martínez-Díaz, M.; Soriguera, F.; Pérez, I. Technology: A necessary but not sufficient condition for future personal mobility. Sustainability 2018, 10, 4141. [CrossRef]

5. Blyth, P.; Mladenovic, M.N.; Nardi, B.A.; Ekbia, H.R.; Su, N.M. Expanding the design horizon for self-driving vehicles: Distributing benefits and burdens. IEEE Technol. Soc. Mag. 2016, 35, 44-49. [CrossRef]

6. Weckström, C.; Mladenović, M.N.; Ullah, W.; Nelson, J.D.; Givoni, M.; Bussman, S. User perspectives on emerging mobility services: Expost analysis of Kutsuplus pilot. Res. Transp. Bus. Manag. 2018, 27, 84-97.

7. McCarthy, A.; Spector, S.; Stephenson, J.; Hopkins, D. Deep interventions for a sustainable transport future. Transp. Res. Part D Transp. Environ. 2018, 61, 256-372.

8. Jensen, O.B. Staging Mobilities; Routledge: London, UK, 2013.

9. Abbott, J. Understanding and managing the unknown: The nature of uncertainty in planning. J. Plan. Educ. Res. 2005, 24, 237-251. [CrossRef]

10. Ziegler, W. Envisioning the future. Futures 1991, 23, 516-527. [CrossRef]

11. Marchau, V.A.; Walker, W.E.; Van Wee, G.P. Dynamic adaptive transport policies for handling deep uncertainty. Technol. Forecast. Soc. Chang. 2010, 77, 940-950. [CrossRef] 
12. Mladenović, M.N. How Should We Drive Self-driving Vehicles? Anticipation and Collective Imagination in Planning Mobility Futures. In The Governance of Smart Transportation Systems; Springer: New York, NY, USA, 2019; pp. 103-122.

13. Martens, K. Transport Justice: Designing Fair Transportation Systems; Routledge: London, UK, 2016.

14. Sheller, M. Mobility Justice: The Politics of Movement in an Age of Extremes; Verso Books: London, UK, 2018.

15. Dewar, J.A.; Wachs, M. Transportation Planning, Climate Change, and Decisionmaking under Uncertainty; Transportation Research Board: Washington, DC, USA, 2008.

16. Lyons, G.; Davidson, C. Guidance for transport planning and policymaking in the face of an uncertain future. Transp. Res. Part A Policy Pract. 2016, 88, 104-116. [CrossRef]

17. Cole, S. Dare to dream: Bringing futures into planning. J. Am. Plan. Assoc. 2001, 67, 372-383. [CrossRef]

18. Sydow, J.; Schreyögg, G.; Koch, J. Organizational paths: Path dependency and beyond. Path Dependence and Creation Process in the Emergence of Markets, Technologies and Institutions Convenors. In Proceedings of the 21st EGOS Colloquium, Berlin, Germany, 30 June-2 July 2005.

19. Dunne, A.; Raby, F. Speculative Everything: Design, Fiction, and Social Dreaming; MIT Press: Cambridge, MA, USA, 2013.

20. Savini, F.; Bertolini, L. Urban experimentation as a politics of niches. Environ. Plan. A Econ. Space 2019, 51, 831-848. [CrossRef]

21. Timms, P. Transport models, philosophy and language. Transportation 2008, 35, 395-410. [CrossRef]

22. Næss, P.; Andersen, J.; Nicolaisen, M.S.; Strand, A. Transport modelling in the context of the 'predict and provide' paradigm. Eur. J. Transp. Infrastruct. Res. 2014, 14, 102-121.

23. Mladenović, M.N.; Trifunović, A. The shortcomings of the conventional four step travel demand forecasting process. J. Road Traffic. Eng. 2014, 1, 60.

24. Timms, P.M. Transport utopia: A need for new models. Transp. Next 2007, 50, 25-27.

25. Flyvbjerg, B.; Skamris Holm, M.K.; Buhl, S.L. How (in) accurate are demand forecasts in public works projects? The case of transportation. J. Am. Plan. Assoc. 2005, 71, 131-146. [CrossRef]

26. Parthasarathi, P.; Levinson, D. Post-construction evaluation of traffic forecast accuracy. Transp. Policy 2010, 17, 428-443. [CrossRef]

27. Nicolaisen, M.S.; Ambrasaite, I.; Salling, K.B. Forecasts: Uncertain, inaccurate and biased. In Selected Proceedings from the Annual Transport Conference at Aalborg University; Aalborg Universitet. Trafikforskningsgruppen: Aalborg, Denmark, 2012.

28. Andersson, M.; Brundell-Freij, K.; Eliasson, J. Validation of aggregate reference forecasts for passenger transport. Transp. Res. Part A Policy Pract. 2017, 96, 101-118. [CrossRef]

29. Wachs, M. Forecasting versus envisioning: A new window on the future. J. Am. Plan. Assoc. 2001, 67, 367-372. [CrossRef]

30. Linnenluecke, M.K.; Verreynne, M.-L.; Scheepers, M.J.D.V.; Venter, C. A review of collaborative planning approaches for transformative change towards a sustainable future. J. Clean. Prod. 2017, 142, 3212-3224. [CrossRef]

31. Iden, J.; Methlie, L.B.; Christensen, G.E. The nature of strategic foresight research: A systematic literature review. Technol. Forecast. Soc. Chang. 2017, 116, 87-97. [CrossRef]

32. Wodak, J.; Neale, T. A critical review of the application of environmental scenario exercises. Futures 2015, 73, 176-186. [CrossRef]

33. Amer, M.; Daim, T.U.; Jetter, A. A review of scenario planning. Futures 2013, 46, 23-40. [CrossRef]

34. Rasouli, S.; Timmermans, H. Uncertainty in travel demand forecasting models: Literature review and research agenda. Transp. Lett. 2012, 4, 55-73. [CrossRef]

35. Nowack, M.; Endrikat, J.; Guenther, E. Review of Delphi-based scenario studies: Quality and design considerations. Technol. Forecast. Soc. Chang. 2011, 78, 1603-1615. [CrossRef]

36. Varum, C.A.; Melo, C. Directions in scenario planning literature-A review of the past decades. Futures 2010, 42, 355-369. [CrossRef]

37. McDowall, W.; Eames, M. Forecasts, scenarios, visions, backcasts and roadmaps to the hydrogen economy: A review of the hydrogen futures literature. Energy Policy 2006, 34, 1236-1250. [CrossRef]

38. Tapio, P.; Hietanen, O. Epistemology and public policy: Using a new typology to analyse the paradigm shift in Finnish transport futures studies. Futures 2002, 34, 597-620. [CrossRef]

39. Davoudi, S. Planning as practice of knowing. Plan. Theory 2015, 14, 316-331. [CrossRef] 
40. Blackler, F. Knowledge, knowledge work and organizations: An overview and interpretation. Organ. Stud. 1995, 16, 1021-1046. [CrossRef]

41. Popper, R. How are foresight methods selected? Foresight 2008, 10, 62-89. [CrossRef]

42. Albrechts, L.; Barbanente, A.; Monno, V. From stage-managed planning towards a more imaginative and inclusive strategic spatial planning. Environ. Plan. C Politics Space 2019, 37, 1489-1506. [CrossRef]

43. Healey, P. Relational complexity and the imaginative power of strategic spatial planning. Eur. Plan. Stud. 2006, 14, 525-546. [CrossRef]

44. Portugali, J.; Meyer, H.; Stolk, E.; Tan, E. Complexity Theories of Cities have Come of Age: An Overview with Implications to Urban Planning and Design; Springer Science \& Business Media: Berlin, Germany, 2012.

45. Sengupta, U.; Rauws, W.S.; de Roo, G. Planning and complexity: Engaging with temporal dynamics, uncertainty and complex adaptive systems. Environ. Plan. B Plan. Des. 2016, 43, 970-974. [CrossRef]

46. Healey, P. Creativity and urban governance. Policy Stud. 2004, 25, 87-102. [CrossRef]

47. Albrechts, L. Creativity as a drive for change. Plan. Theory 2005, 4, 247-269. [CrossRef]

48. Kind, A. Introduction: Exploring imagination. In The Routledge Handbook of Philosophy of Imagination; Routledge: New York, NY, USA, 2016; pp. 1-12.

49. Van Leeuwen, N. The meanings of "imagine" part I: Constructive imagination. Philos. Compass 2013,8, 220-230. [CrossRef]

50. Currie, G.; Ravenscroft, I. Recreative Minds: Imagination in Philosophy and Psychology; Oxford University Press: New York, NY, USA, 2002.

51. Sandercock, L. Towards a planning imagination for the 21st century. J. Am. Plan. Assoc. 2004, 70, $133-141$. [CrossRef]

52. Healey, P. Urban Complexity and Spatial Strategies: Towards a Relational Planning for Our Times; Routledge: New York, NY, USA, 2006.

53. Davoudi, S.; Crawford, J.; Raynor, R.; Reid, B.; Sykes, O.; Shaw, D. Policy and Practice Spatial imaginaries: Tyrannies or transformations? Town Plann. Rev. 2018, 89, 97-124. [CrossRef]

54. Jasanoff, S. The Ethics of Invention: Technology and the Human Future; WW Norton \& Company: New York, NY, USA, 2016.

55. Collie, N. Cities of the imagination: Science fiction, urban space, and community engagement in urban planning. Futures 2011, 43, 424-431. [CrossRef]

56. Westwood, S.; Williams, J.M. Imagining Cities; Routledge: London, UK, 2018.

57. Wee, B.V.; Banister, D. How to write a literature review paper? Transp. Rev. 2016, 36, 278-288. [CrossRef]

58. Moher, D.; Liberati, A.; Tetzlaff, J.; Altman, D.G. Preferred reporting items for systematic reviews and meta-analyses: The PRISMA statement. Ann. Intern. Med. 2009, 151, 264-269. [CrossRef] [PubMed]

59. Jalali, S.; Wohlin, C. Systematic literature studies: Database searches vs. backward snowballing. In Proceedings of the 2012 ACM-IEEE International Symposium on Empirical Software Engineering and Measurement, Lund, Sweden, 20-21 September 2012; pp. 29-38.

60. Wohlin, C. Guidelines for snowballing in systematic literature studies and a replication in software engineering. In Proceedings of the 18th International Conference on Evaluation and Assessment in Software Engineering, London, UK, 13-14 May 2014; p. 38.

61. Chow, J.Y.; Yang, C.H.; Regan, A.C. State-of-the art of freight forecast modeling: Lessons learned and the road ahead. Transportation 2010, 37, 1011-1030. [CrossRef]

62. Ian Miles, C. Appraisal of alternative methods and procedures for producing Regional Foresight. In European Commission's DG Research Funded STRATA-ETAN Expert Group Action; University of Manchester: Manchester, UK, 2002.

63. Khakee, A. Futures-oriented municipal planning. Technol. Forecast Soc. 1985, 1, 63-83. [CrossRef]

64. Drew, S.A. Building technology foresight: Using scenarios to embrace innovation. Eur. J. Innov. Manag. 2006, 9, 241-257. [CrossRef]

65. Börjeson, L.; Höjer, M.; Dreborg, K.; Ekvall, T.; Finnveden, G. Scenario types and techniques: Towards a user's guide. Futures 2006, 38, 723-739. [CrossRef]

66. Bartholomew, K.; Ewing, R. Land use-transportation scenario planning in an era of global climate change. In Proceedings of the 87th Annual Meeting of the Transportation Research Board, Washington, DC, USA, 13-17 January 2008. 
67. Bartholomew, K. Land use-transportation scenario planning: Promise and reality. Transportation 2007, 34, 397-412. [CrossRef]

68. Rubulotta, E.; Ignaccolo, M.; Inturri, G.; Rofè, Y. Accessibility and centrality for sustainable mobility: Regional planning case study. J. Urban Plan. Dev. 2012, 139, 115-132. [CrossRef]

69. Fuglsang, M.; Hansen, H.S.; Münier, B. Accessibility analysis and modelling in public transport networks-A raster based approach. In Proceedings of the International Conference on Computational Science and Its Applications, Santander, Spain, 20-23 June 2011; Springer: Berlin/Heidelberg, Germany, 2011; pp. 207-224.

70. Schroeder, M.J.; Lambert, J.H. Scenario-based multiple criteria analysis for infrastructure policy impacts and planning. J. Risk Res. 2011, 14, 191-214. [CrossRef]

71. Saleh, M.; Agami, N.; Omran, A.; El-Shishiny, H. A survey on futures studies methods. In Proceedings of the 6th International Conference on Informatics and Systems, Cairo, Egypt, 27-29 March 2008.

72. Mankoff, J.; Rode, J.A.; Faste, H. Looking past yesterday's tomorrow: Using futures studies methods to extend the research horizon. In Proceedings of the SIGCHI Conference on Human Factors in Computing Systems, Paris, France, 27 April-2 May 2013; Association for Computing Machinery: New York, NY, USA, 2013; pp. 1629-1638.

73. Von der Gracht Heiko, A.; Darkow, I. Energy-constrained and low-carbon scenarios for the transportation and logistics industry. Int. J. Logist. Manag. 2016, 27, 142-166. [CrossRef]

74. Anable, J.; Lane, B.; Banks, N. The MPG Paradox: Why car purchasers say they care about fuel economy, but don't, A 2009 update Act! Innovate! Deliver! Reducing energy demand sustainability. In Proceedings of the European Council for an Energy Efficient Economy 2009 Summer Study, La Colle sur Loup, France, 1-6 June 2009; ECEEE: Stockholm, Sweden, 2009.

75. Byers, E.A.; Gasparatos, A.; Serrenho, A.C. A framework for the exergy analysis of future transport pathways: Application for the United Kingdom transport system 2010-2050. Energy 2015, 88, 849-862. [CrossRef]

76. Banister, D.; Hickman, R. Transport futures: Thinking the unthinkable. Transp. Policy 2013, 29, $283-293$. [CrossRef]

77. Wangel, J.; Gustafsson, S.; Svane, Ö. Goal-based socio-technical scenarios: Greening the mobility practices in the Stockholm City District of Bromma, Sweden. Futures 2013, 47, 79-92. [CrossRef]

78. Weddfelt, E.; Vaccari, M.; Tudor, T. The development of environmental visions and strategies at the municipal level: Case studies from the county of Östergötland in Sweden. J. Environ. Manag. 2016, 179, 76-82. [CrossRef]

79. Landau, L.B.; Segatti, A.; Misago, J.P. Planning and participation in cities that move: Identifying obstacles to municipal mobility management. Public Adm. Dev. 2013, 33, 113-124. [CrossRef]

80. Varho, V.; Tapio, P. Combining the qualitative and quantitative with the Q2 scenario technique-The case of transport and climate. Technol. Forecast. Soc. Chang. 2013, 80, 611-630. [CrossRef]

81. Liimatainen, H.; Kallionpää, E.; Pöllänen, M.; Stenholm, P.; Tapio, P.; McKinnon, A. Decarbonizing road freight in the future-Detailed scenarios of the carbon emissions of Finnish road freight transport in 2030 using a Delphi method approach. Technol. Forecast. Soc. Chang. 2014, 81, 177-191. [CrossRef]

82. Shaw, A.; Sheppard, S.; Burch, S.; Flanders, D.; Wiek, A.; Carmichael, J.; Robinson, J.; Cohen, S. Making local futures tangible-Synthesizing, downscaling, and visualizing climate change scenarios for participatory capacity building. Glob. Environ. Chang. 2009, 19, 447-463. [CrossRef]

83. Moriarty, P.; Honnery, D. Low-mobility: The future of transport. Futures 2008, 40, 865-872. [CrossRef]

84. Brady, J.; O'Mahony, M. Travel to work in Dublin. The potential impacts of electric vehicles on climate change and urban air quality. Transp. Res. Part D Transp. Environ. 2011, 16, 188-193. [CrossRef]

85. Clover, D.G. The Market for Electric Vehicles in New Zealand: Using Stated Choice Methods to Evaluate the Implications for Electricity Demand and Carbon Emissions to 2030. Ph.D. Thesis, Victoria University of Wellington, Wellington, New Zealand, 2013.

86. Lindfeldt, E.G.; Saxe, M.; Magnusson, M.; Mohseni, F. Strategies for a road transport system based on renewable resources-The case of an import-independent Sweden in 2025. Appl. Energy 2010, 87, 1836-1845. [CrossRef]

87. Stead, D.; Banister, D. Transport policy scenario-building. Transp. Plan. Technol. 2003, 26, 513-536. [CrossRef]

88. Schwanen, T.; Banister, D.; Anable, J. Scientific research about climate change mitigation in transport: A critical review. Transp. Res. Part A Policy Pract. 2011, 45, 993-1006. [CrossRef]

89. Banister, D. Cities, mobility and climate change. J. Transp. Geogr. 2011, 19, 1538-1546. [CrossRef] 
90. Dubois, G.; Peeters, P.; Ceron, J.; Gössling, S. The future tourism mobility of the world population: Emission growth versus climate policy. Transp. Res. Part A Policy Pract. 2011, 45, 1031-1042. [CrossRef]

91. Hickman, R.; Ashiru, O.; Banister, D. Transitions to low carbon transport futures: Strategic conversations from London and Delhi. J. Transp. Geogr. 2011, 19, 1553-1562. [CrossRef]

92. Khakee, A. Participatory scenarios for sustainable development. Foresight 1999, 1, 229-240. [CrossRef]

93. Coppola, R.; Morisio, M. Connected car: Technologies, issues, future trends. ACM Comput. Surv. 2016, $49,46$. [CrossRef]

94. Bagloee, S.A.; Tavana, M.; Asadi, M.; Oliver, T. Autonomous vehicles: Challenges, opportunities, and future implications for transportation policies. J. Mod. Transp. 2016, 24, 284-303. [CrossRef]

95. Milakis, D.; Van Arem, B.; Van Wee, B. Policy and society related implications of automated driving: A review of literature and directions for future research. J. Intell. Transp. Syst. 2017, 21, 324-348. [CrossRef]

96. Åkerman, J.; Höjer, M. How much transport can the climate stand?-Sweden on a sustainable path in 2050. Energy Policy 2006, 34, 1944-1957. [CrossRef]

97. Robèrt, M.; Jonsson, R.D. Assessment of transport policies toward future emission targets: A backcasting approach for Stockholm 2030. J. Environ. Assess. Policy Manag. 2006, 8, 451-478. [CrossRef]

98. Hickman, R.; Banister, D. Looking over the horizon: Transport and reduced $\mathrm{CO}_{2}$ emissions in the UK by 2030. Transp. Policy 2007, 14, 377-387. [CrossRef]

99. Hickman, R.; Ashiru, O.; Banister, D. Achieving carbon-efficient transportation: Backcasting from London. Transp. Res. Rec. 2009, 2139, 172-182. [CrossRef]

100. Wangel, J. Exploring social structures and agency in backcasting studies for sustainable development. Technol. Forecast. Soc. Chang. 2011, 78, 872-882. [CrossRef]

101. Williams, A. Product service systems in the automobile industry: Contribution to system innovation? J. Clean. Prod. 2007, 15, 1093-1103. [CrossRef]

102. Arena, M.; Azzone, G.; Colorni, A.; Conte, A.; Luè, A.; Nocerino, R. Service design in electric vehicle sharing: Evidence from Italy. IET Intell. Transp. Syst. 2014, 9, 145-155. [CrossRef]

103. Morton, C.; Budd, T.M.; Harrison, G.; Mattioli, G. Exploring the expectations of transport professionals concerning the future automobility system: Visions, challenges, and transitions. Int. J. Sustain. Transp. 2017, 11, 493-506. [CrossRef]

104. Marletto, G. Car and the city: Socio-technical transition pathways to 2030. Technol. Forecast. Soc. Chang. 2014, 87, 164-178. [CrossRef]

105. Jahnke, M. Meaning in the Making: Introducing a hermeneutic perspective on the contribution of design practice to innovation. Ph.D. Thesis, School of Design and Crafts, Faculty of Fine, Applied and Performing Arts, University of Gothenburg, Gothenburg, Sweden, 2013.

106. Stark, R.; Buchert, T.; Neugebauer, S.; Bonvoisin, J.; Finkbeiner, M. Benefits and obstacles of sustainable product development methods: A case study in the field of urban mobility. Des. Sci. 2017, 3, e17. [CrossRef]

107. Ryghaug, M.; Toftaker, M. A transformative practice? Meaning, competence, and material aspects of driving electric cars in Norway. Nat. Cult. 2014, 9, 146-163. [CrossRef]

108. Diewald, S.; Möller, A.; Stockinger, T.; Roalter, L.; Koelle, M.; Lindemann, P.; Kranz, M. Gamification-supported exploration and practicing for automotive user interfaces and vehicle functions. In Gamification in Education and Business; Springer: Berlin/Heidelberg, Germany, 2015; pp. 637-661.

109. Steinberger, F.; Proppe, P.; Schroeter, R.; Alt, F. CoastMaster: An ambient speedometer to gamify safe driving. In Proceedings of the 8th International Conference on Automotive User Interfaces and Interactive Vehicular Applications, Ann Arbor, MI, USA, 24-26 October 2016; Association for Computing Machinery: New York, NY, USA, 2016; pp. 83-90.

110. Kazhamiakin, R.; Marconi, A.; Martinelli, A.; Pistore, M.; Valetto, G. A gamification framework for the long-term engagement of smart citizens. In Proceedings of the 2016 IEEE International Smart Cities Conference (ISC2), Trento, Italy, 12-15 September 2016; pp. 1-7.

111. Klein, I.; Ben-Elia, E. Emergence of cooperation in congested road networks using ICT and future and emerging technologies: A game-based review. Transp. Res. Part C Emerg. Technol. 2016, 72, 10-28. [CrossRef]

112. Warth, J.; Heiko, A.; Darkow, I. A dissent-based approach for multi-stakeholder scenario development-The future of electric drive vehicles. Technol. Forecast. Soc. Chang. 2013, 80, 566-583. [CrossRef] 
113. Bailey, R.; Longhurst, J.W.; Hayes, E.T.; Hudson, L.; Ragnarsdottir, K.V.; Thumim, J. Exploring a city's potential low carbon futures using Delphi methods: Some preliminary findings. J. Environ. Plan. Manag. 2012, 55, 1022-1046. [CrossRef]

114. Förster, B.; von der Gracht, H. Assessing Delphi panel composition for strategic foresight-A comparison of panels based on company-internal and external participants. Technol. Forecast. Soc. Chang. 2014, 84, $215-229$. [CrossRef]

115. Battistella, C.; Pillon, R. Foresight for regional policy: Technological and regional fit. Foresight 2016, 18, 93-116. [CrossRef]

116. Van Zuylen, H.J.; Weber, K.M. Strategies for European innovation policy in the transport field. Technol. Forecast. Soc. Chang. 2002, 69, 929-951. [CrossRef]

117. Spickermann, A.; Grienitz, V.; Heiko, A. Heading towards a multimodal city of the future? Multi-stakeholder scenarios for urban mobility. Technol. Forecast. Soc. Chang. 2014, 89, 201-221. [CrossRef]

118. Julsrud, T.E.; Uteng, T.P. Technopolis, shared resources or controlled mobility? A net-based Delphi-study to explore visions of future urban daily mobility in Norway. Eur. J. Futures Res. 2015, 3, 10. [CrossRef]

119. Schuckmann, S.W.; Gnatzy, T.; Darkow, I.; Heiko, A. Analysis of factors influencing the development of transport infrastructure until the year 2030-A Delphi based scenario study. Technol. Forecast. Soc. Chang. 2012, 79, 1373-1387. [CrossRef]

120. Tapio, P. Disaggregative policy Delphi: Using cluster analysis as a tool for systematic scenario formation. Technol. Forecast. Soc. Chang. 2003, 70, 83-101. [CrossRef]

121. Kok, K.; Rothman, D.S.; Patel, M. Multi-scale narratives from an IA perspective: Part I. European and Mediterranean scenario development. Futures 2006, 38, 261-284. [CrossRef]

122. Larsen, K.; Gunnarsson-Östling, U.; Westholm, E. Environmental scenarios and local-global level of community engagement: Environmental justice, jams, institutions and innovation. Futures 2011, 43, 413-423. [CrossRef]

123. Hult, A.; Bradley, K. Planning for sharing-providing infrastructure for citizens to be makers and sharers. Plan. Theory Pract. 2017, 18, 597-615. [CrossRef]

124. Camacho, T.; Foth, M.; Rakotonirainy, A.; Rittenbruch, M.; Bunker, J. The role of passenger-centric innovation in the future of public transport. Public Transp. 2016, 8, 453-475. [CrossRef]

125. van der Bijl-Brouwer, M.; Dorst, K. Advancing the strategic impact of human-centred design. Des. Stud. 2017, 53, 1-23. [CrossRef]

126. Ramm, S.; Giacomin, J.; Malizia, A.; Anyasodo, B. An exploratory design workshop to elicit what feels natural when interacting with an automobile's secondary controls. Des. J. 2018, 21, 109-137. [CrossRef]

127. Lezaun, J.; Soneryd, L. Consulting citizens: Technologies of elicitation and the mobility of publics. Public Underst. Sci. 2007, 16, 279-297. [CrossRef]

128. Evans, J.; Karvonen, A. Living laboratories for sustainability: Exploring the politics and epistemology of urban transition. In Cities and Low Carbon Transitions; Routledge: London, UK, 2011; pp. 126-141.

129. Voytenko, Y.; McCormick, K.; Evans, J.; Schliwa, G. Urban living labs for sustainability and low carbon cities in Europe: Towards a research agenda. J. Clean. Prod. 2016, 123, 45-54. [CrossRef]

130. Natarajan, L. Socio-spatial learning: A case study of community knowledge in participatory spatial planning. Prog. Plan. 2017, 111, 1-23. [CrossRef]

131. Legacy, C. Transforming transport planning in the postpolitical era. Urban Stud. 2016, 53, 3108-3124. [CrossRef]

132. Holmer, H.B.; DiSalvo, C.; Sengers, P.; Lodato, T. Constructing and constraining participation in participatory arts and HCI. Int. J. Hum. Comput. Stud. 2015, 74, 107-123. [CrossRef]

133. Tuominen, A.; Tapio, P.; Varho, V.; Järvi, T.; Banister, D. Pluralistic backcasting: Integrating multiple visions with policy packages for transport climate policy. Futures 2014, 60, 41-58. [CrossRef]

134. Järvi, T.; Tuominen, A.; Tapio, P.; Varho, V. A transport policy tool for reduction of $\mathrm{CO}_{2}$ emissions in Finland-Visions, scenarios and pathways using pluralistic backcasting method. Transp. Res. Procedia 2015, 11, 185-198. [CrossRef]

135. Soria-Lara, J.A.; Banister, D. Dynamic participation processes for policy packaging in transport backcasting studies. Transp. Policy 2017, 58, 19-30. [CrossRef] 
136. Ilstedt, S.; Wangel, J. Altering expectations: How design fictions and backcasting can leverage sustainable lifestyles. In Proceedings of the DRS (Design Research Society) 2014: Design's Big Debates-Pushing the Boundaries of Design Research, Umeå, Sweden, 16-19 June 2014.

137. Dixon, T.; Eames, M.; Britnell, J.; Watson, G.B.; Hunt, M. Urban retrofitting: Identifying disruptive and sustaining technologies using performative and foresight techniques. Technol. Forecast. Soc. Chang. 2014, 89, 131-144. [CrossRef]

138. Milestad, R.; Svenfelt, Å.; Dreborg, K.H. Developing integrated explorative and normative scenarios: The case of future land use in a climate-neutral Sweden. Futures 2014, 60, 59-71. [CrossRef]

139. Zimmermann, M.; Darkow, I.; Heiko, A. Integrating Delphi and participatory backcasting in pursuit of trustworthiness-the case of electric mobility in Germany. Technol. Forecast. Soc. Chang. 2012, 79, 1605-1621. [CrossRef]

140. Havas, A.; Schartinger, D.; Weber, M. The impact of foresight on innovation policy-making: Recent experiences and future perspectives. Res. Eval. 2010, 19, 91-104. [CrossRef]

141. Pollastri, S.; Boyko, C.; Cooper, R.; Dunn, N.; Clune, S.; Coulton, C. Envisioning urban futures: From narratives to composites. Des. J. 2017, 20, S4365-S4377. [CrossRef]

142. Kurniawan, J.H. Scenario Development Process for the Future of Urban Mobility 2040; Future of Urban Transport Working Paper Series; Singapore University of Technology and Design: Singapore, 2016. [CrossRef]

143. Mathy, S.; Fink, M.; Bibas, R. Rethinking the role of scenarios: Participatory scripting of low-carbon scenarios for France. Energy Policy 2015, 77, 176-190. [CrossRef]

144. Gudowsky, N.; Sotoudeh, M.; Capari, L.; Wilfing, H. Transdisciplinary forward-looking agenda setting for age-friendly, human centered cities. Futures 2017, 90, 16-30. [CrossRef]

145. Povey, D.; Demming, J.; Kay, W.; Rahr, L.; Thieman, C. Tillamook County Futures: A Citizen Based Approach to Developing County Visions, Goals, Strategies and Benchmarks, Tillamook County Futures Council; University of Oregon: Eugene, OR, USA, 1999.

146. Shipley, R.; Feick, R.; Hall, B.; Earley, R. Evaluating municipal visioning. Plan. Pract. Res. 2004, 19, $195-210$. [CrossRef]

147. Eames, M.; Dixon, T.; May, T.; Hunt, M. City futures: Exploring urban retrofit and sustainable transitions. Build. Res. Inf. 2013, 41, 504-516. [CrossRef]

148. Stich, B.M. Community Visioning in Long-Range Transportation Planning: A Case Study of Virginia. Ph.D. Thesis, Graduate Faculty of The Center for Public Administration, Public Affairs, Virginia Polytechnic Institute and State University, Blacksburg, VA, USA, 2006.

149. Tight, M.; Timms, P.; Banister, D.; Bowmaker, J.; Copas, J.; Day, A.; Drinkwater, D.; Givoni, M.; Gühnemann, A.; Lawler, M. Visions for a walking and cycling focussed urban transport system. J. Transp. Geogr. 2011, 19, 1580-1589. [CrossRef]

150. Bergman, N.; Schwanen, T.; Sovacool, B.K. Imagined people, behaviour and future mobility: Insights from visions of electric vehicles and car clubs in the United Kingdom. Transp. Policy 2017, 59, 165-173. [CrossRef]

151. Stead, D. Key research themes on governance and sustainable urban mobility. Int. J. Sustain. Transp. 2016, 10, 40-48. [CrossRef]

152. Marisa, G.; Elisa, B.; Walter, M. Piredda Francesca Envisioning the city: A design-oriented communication process for a sustainable urban transformation. In Proceedings of the ESA research network sociology of culture midterm conference: Culture and the making of worlds, Milan, Italy, 7-9 October 2010; Social Science Research Network: Milan, Italy, 2010; pp. 1-12.

153. Ryan, C.; Gaziulusoy, I.; McCormick, K.; Trudgeon, M. Virtual city experimentation: A critical role for design visioning. In The Experimental City; Routledge: London, UK, 2016; pp. 61-76.

154. Koivisto, R.; Kulmala, I.; Gotcheva, N. Weak signals and damage scenarios-Systematics to identify weak signals and their sources related to mass transport attacks. Technol. Forecast. Soc. Chang. 2016, 104, 180-190. [CrossRef]

155. Saritas, O.; Smith, J.E. The big picture-trends, drivers, wild cards, discontinuities and weak signals. Futures 2011, 43, 292-312. [CrossRef]

156. Söderström, O.; Paasche, T.; Klauser, F. Smart cities as corporate storytelling. City 2014, 18, 307-320. [CrossRef]

157. Fortes, P.; Alvarenga, A.; Seixas, J.; Rodrigues, S. Long-term energy scenarios: Bridging the gap between socio-economic storylines and energy modeling. Technol. Forecast. Soc. Chang. 2015, 91, 161-178. [CrossRef] 
158. Bertolini, L. Integrating mobility and urban development agendas: A manifesto. disP-Plan. Rev. 2012, 48, 16-26. [CrossRef]

159. Auger, J. Alternative Presents and Speculative Futures: Designing fictions through the extrapolation and evasion of product lineages. Negot. Futures-Des. Fict. 2010, 6, 42-57.

160. DiSalvo, C. FCJ-142 Spectacles and tropes: Speculative design and contemporary food cultures. Fibreculture J. 2012, 48, 16-26.

161. Gruel, W.; Stanford, J.M. Assessing the long-term effects of autonomous vehicles: A speculative approach. Transp. Res. Procedia 2016, 13, 18-29. [CrossRef]

162. Bleecker, J. Design Fiction: A short essay on design, science, fact and fiction. Near Future Lab. 2009, $29,6$.

163. Knutz, E.; Markussen, T. The Role of Fiction in Experiments within Design, Art \& Architecture-Towards a New Typology of Design Fiction. Artifact J. Des. Pract. 2014, 3, 1-8.

164. Sterling, B. COVER STORY: Design fiction. Interactions 2009, 16, 20-24. [CrossRef]

165. DiSalvo, C.; Jenkins, T.; Lodato, T. Designing speculative civics. In Proceedings of the 2016 CHI Conference on Human Factors in Computing Systems Problem-solving or not? The Boundaries of HCI Research, San Hose, CA, USA, 7-12 May 2016; Association for Computing Machinery: New York, NY, USA, 2016; pp. 4979-4990.

166. Celi, M.; Formia, E. Aesthetics of futures. Shaping shared visions of tomorrow. Des. J. 2017, 20, S63-S76. [CrossRef]

167. Dourish, P.; Bell, G. Resistance is futile: Reading science fiction alongside ubiquitous computing. Pers. Ubiquitous Comput. 2014, 18, 769-778. [CrossRef]

168. Bassett, C.; Steinmueller, E.; Voss, G. Better made up: The mutual influence of science fiction and innovation. Nesta Work Pap. 2013, 13, 1-52.

169. Bell, F.; Fletcher, G.; Greenhill, A.; Griffiths, M.; McLean, R. Science fiction prototypes: Visionary technology narratives between futures. Futures 2013, 50, 5-14. [CrossRef]

170. Pirker, J.; Gütl, C.; Weghofer, P.; Feichtner, V. Interactive Science Fiction Prototyping in Virtual Worlds: Fundamentals and Applications. Int. J. Recent Contrib. Eng. Sci. IT 2014, 2, 46-52. [CrossRef]

171. von Stackelberg, P.; McDowell, A. What in the world? Storyworlds, science fiction, and futures studies. J. Futures Stud. 2015, 20, 25-46.

172. Pooley, C.G. Landscapes without the car: A counterfactual historical geography of twentieth-century Britain. J. Hist. Geogr. 2010, 36, 266-275. [CrossRef]

173. Hayden, A.; Tight, M.; Burrow, M. Is reducing car use a utopian vision? Transp. Res. Procedia 2017, 25, 3944-3956. [CrossRef]

174. Urry, J. Climate change, travel and complex futures 1. Br. J. Sociol. 2008, 59, 261-279. [CrossRef]

175. Timms, P.; Tight, M.; Watling, D. Imagineering mobility: Constructing utopias for future urban transport. Environ. Plan. A 2014, 46, 78-93. [CrossRef]

176. Veselova, E.; Gaziulusoy, A.İ. Implications of the Bioinclusive Ethic on Collaborative and Participatory Design. Des. J. 2019, 22, 1571-1586. [CrossRef]

177. Vallet, F.; Puchinger, J.; Millonig, A.; Lamé, G.; Nicolaï, I. Tangible futures: Combining scenario thinking and personas-A pilot study on urban mobility. Futures 2020, 117, 102513. [CrossRef]

178. Mladenović, M.N.; Lehtinen, S.; Soh, E.; Martens, K. Emerging Urban Mobility Technologies through the Lens of Everyday Urban Aesthetics: Case of Self-Driving Vehicle. Essays Philos. 2019, 20, 146-170. [CrossRef]

179. Inayatullah, S.; Izgarjan, A.; Kuusi, O.; Minkkinen, M. Metaphors in futures research. Metaphors in futures research. Futures 2016, 84, 109-114. [CrossRef]

180. Judge, A. Metaphor as fundamental to future discourse. Futures 2016, 84, 115-119. [CrossRef]

181. Milojević, I.; Inayatullah, S. Narrative foresight. Futures 2015, 73, 151-162. [CrossRef]

182. Pangbourne, K.; Mladenović, M.N.; Stead, D.; Milakis, D. Questioning mobility as a service: Unanticipated implications for society and governance. Transp. Res. Part A Policy Pract. 2020, 131, 35-49. [CrossRef]

183. Mladenovic, M.N.; Stead, D.; Milakis, D.; Pangbourne, K.; Givoni, M. Governance cultures and socio-technical imaginaries of self-driving technology: Comparative analysis of Finland, UK and Germany. In Policy Implications of Autonomous Vehicles. Advances in Transport Policy and Planning, 5; Milakis, D., Thomopoulos, N., van Wee, B., Eds.; Academic Press University of Leeds: Leeds, UK, 2019. [CrossRef]

184. Alcamo, J. Environmental Futures: The Practice of Environmental Scenario Analysis; Elsevier: Amsterdam, The Netherlands; Boston, MA, USA, 2008. 
185. Caris, A.; Macharis, C.; Janssens, G.K. Decision support in intermodal transport: A new research agenda. Comput. Ind. 2013, 64, 105-112. [CrossRef]

186. Eräranta, S. Memorize the Dance in the Shadows?-Unriddling the Networked Dynamics of Planning Processes through Social Network Analysis. Ph.D. Thesis, Aalto University School of Engineering, Espoo, Finland, 1 March 2019.

187. Mladenović, M.N.; Eräranta, S. Hear the Rime of the Fellow Mariner? A Letter to the Next Generation of Emphatic Co-Creators in Planning. Plan. Theory Pract. 2020, 21, 164-174. [CrossRef]

188. Albort-Morant, G.; Henseler, J.; Leal-Millán, A.; Cepeda-Carrión, G. Mapping the field: A bibliometric analysis of green innovation. Sustainability 2017, 9, 1011. [CrossRef]

C 2020 by the authors. Licensee MDPI, Basel, Switzerland. This article is an open access article distributed under the terms and conditions of the Creative Commons Attribution (CC BY) license (http://creativecommons.org/licenses/by/4.0/). 